Florida International University FIU Digital Commons

$11-14-2011$

\title{
Resource Partitioning Among Three Mesoconsumers at a Marsh Mangrove Ecotone: a Response to a Seasonal Resource Pulse Subsidy
}

Ross E. Boucek

Florida International University, rbouc003@fiu.edu

DOI: $10.25148 /$ etd.FI1 1120918

Follow this and additional works at: https://digitalcommons.fiu.edu/etd

\section{Recommended Citation}

Boucek, Ross E., "Resource Partitioning Among Three Mesoconsumers at a Marsh Mangrove Ecotone: a Response to a Seasonal Resource Pulse Subsidy" (2011). FIU Electronic Theses and Dissertations. 541.

https://digitalcommons.fiu.edu/etd/541 


\section{FLORIDA INTERNATIONAL UNIVERSITY \\ Miami, Florida}

\section{RESOURCE PARTITIONING AMONG THREE MESOCONSUMERS AT A MARSH MANGROVE ECOTONE: A RESPONSE TO A SEASONAL RESOURCE PULSE SUBSIDY}

A thesis submitted in partial fulfillment of the requirements for the degree of MASTER OF SCIENCE in ENVIRONMENTAL STUDIES

by

Ross Boucek 
To: Dean Kenneth G. Furton

College of Arts and Sciences

This thesis, written by Ross Boucek, and entitled Resource Partitioning Among Three Mesoconsumers at a Marsh Mangrove Ecotone: a Response to a Seasonal Resource Pulse Subsidy, having been approved in respect to style and intellectual content, is referred to you for judgment.

We have read this thesis and recommend that it be approved.

Michael Heithaus

Aaron Adams

Craig Layman

Jennifer Rehage, Major Professor

Date of Defense: November $14^{\text {th }} 2011$

The thesis of Ross Boucek is approved.

Dean Kenneth G. Furton

College of Arts and Sciences

Dean Lakshmi Reddi

Division of Graduate Studies

Florida International University, 2011 


\begin{abstract}
OF THE THESIS
RESOURCE PARTITIONING AMONG THREE MESOCONSUMERS AT A MARSH

MANGROVE ECOTONE: A RESPONSE TO A SEASONAL RESOURCE PULSE

SUBSIDY

by
\end{abstract}

Ross Boucek

Florida International University, 2011

Miami, Florida

Professor Jennifer Rehage, Major Professor

Pulse subsidies account for a substantial proportion of resource availability in many systems, having persistent and cascading effects on consumer population dynamics, and the routing of energy within and across ecosystem boundaries. Although the importance of resource pulses is well-established, consumer responses and the extent of resource partitioning is not well understood. I identified a pulse of marsh cyprinodontoid, invertebrate, and sunfish prey, entering an estuary, which was met by an influx of both marsh and estuarine predators. In response to the pulse, consumers showed marked diet segregation. Bass consumed significantly more cyprinodontoids, bowfin consumed significantly more invertebrates, and snook almost exclusively targeted sunfishes. The diversity of the resource pulse subsidizes multiple consumers, routing pulsed production through various trophic pathways and across ecosystem boundaries. Preserving complex trophic linkages like those of the Everglades ecotone may be important to maintaining ecosystem function and the provisioning of services, such as recreational fisheries. 


\section{TABLE OF CONTENTS}

CHAPTER

PAGE

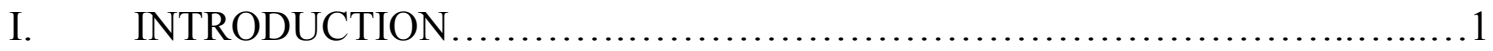

II. METHODS .....................................................................

Study

System............................................................. 5

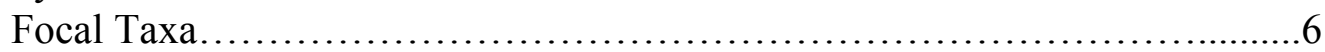

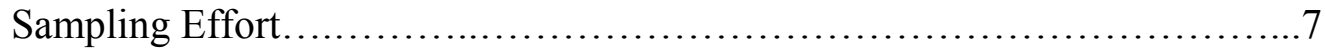

Statistical Analyses...................................................... 10

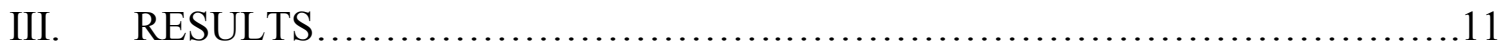

Pulse Dynamics: Small Prey.............................................11

Sunfish Prey and Consumer CPUE.......................................12

Stomach

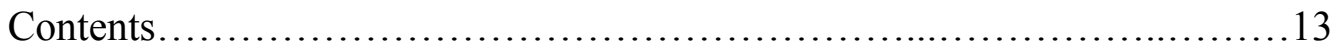

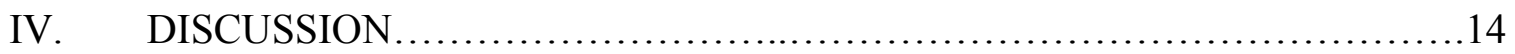

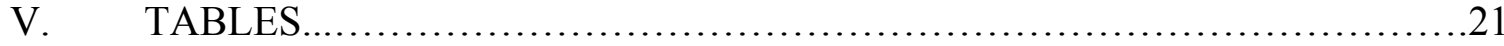

Summary ANOVA Table of Predator \& Prey Demographics....................21

Summary Scheirer-Ray-Hare test Table of Predator Stomach Content Data.....22

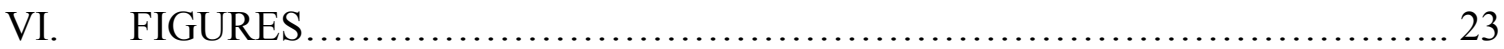

LIST OF REFERENCES ................................................ 28 


\section{LIST OF FIGURES}

FIGURE

PAGE

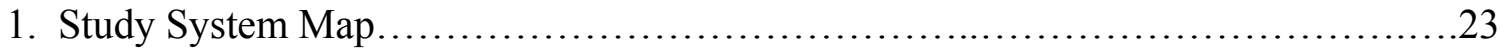

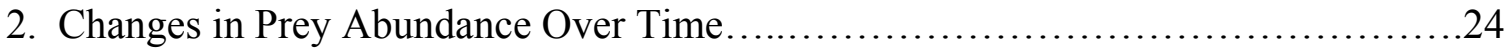

3. Changes in Predator Abundance Over Time.......................................25

4. Changes in Proportion of Full Stomachs Across Seasons............................26

5. Mean Numerical Proportions of Prey Found Within Diets of Consumers.............27 


\section{FIGURE CAPTIONS}

FIGURE 1. Map showing the location of the five study sites in Rookery Branch in the upper Shark River, ENP. Study sites are shown in black circles, and black squares denote hydrological stations.

FIGURE 2. Variation in prey CPUE (catch per unit effort) over sampling events for A) cyprinodontoids (white bars) and invertebrates (gray bars) caught in minnow traps, and B) for sunfishes caught via electrofishing. The solid black line shows marsh water depth (USGS hydrostation SH1) over the period of sampling. The dashed line indicates complete marsh drying.

FIGURE 3. A) Variation in electrofishing CPUE (\# of fish per $100 \mathrm{~m}$ of mangrove shoreline), and B) fish size (standard length for snook and bass, and total length for bowfin) for the three focal consumer species: bass (dotted black), bowfin (dashed light grey), and snook (solid dark gray).

FIGURE 4. Mean proportion of full stomachs per electrofishing bout across the four seasons for bass (dotted black), bowfin (dashed light grey), and snook (solid dark gray).

FIGURE 5. Mean numerical proportion of A) cyprinodontoids, B) macroinvertebrates, and C) sunfishes per stomach sampled across seasons for bass (dotted black), bowfin (dashed light grey), and snook (solid dark gray 


\section{INTRODUCTION}

The importance of pulsed resources in driving ecological dynamics across multiple scales of organization has become increasingly accepted by ecologists (Polis et al. 1997; Marczak et al. 2007; Yang et al. 2008). Pulsed resources, defined as rapid increases in resource availability, followed by gradual declines, occur across a wide range of ecosystem types (Ostfeld and Kessing 2000; Yang et al. 2008), and often characterized by brief and intense events of high resource availability (Holt 2008; Yang et al. 2008). Though these spikes in resource availability may appear as outliers across spatiotemporal scales in resource heterogeneity, they can account for a substantial proportion of resources in many systems. Further, they have important effects on consumer abundance and coexistence, as well as food web dynamics and stability (Polis et al. 1997; Ostfeld and Kessing 2000; Huxel et al. 2002). For example, in beaches of the Bahamas, wrack deposited by storm events dramatically increases the abundance of detritivorous insects, which are then exploited by spiders and lizards. These spiders and lizards switch their diets from local herbivorous insects to this newly-available resource, thus releasing local herbivores from predation, and causing up to $70 \%$ decreases in local vegetation densities (Piovia-Scott et al. 2011).

Pulses of energy that cross ecosystem boundaries are considered subsidies (Marczak et al. 2007), and also may have persistent and cascading effects on food web structure and dynamics (Ostfeld and Kessing 2000). These effects are dependent on the frequency and intensity of pulsed events, the diversity of the pulse subsidy, and the trophic placement of pulse consumers (Polis et al. 1998; Anderson et al. 2008). Pulses 
consumed by taxa at lower trophic levels typically result in strong numerical responses, but due to their limited mobility, pulsed production remains localized (Yang et al. 2008). Taxa in upper trophic levels exhibit functional responses, are often mobile, thus easily transport pulsed production across ecosystem boundaries. For example, black bears (Ursus americanus) consume up to $50 \%$ of salmon that pulse into streams of the Pacific Northwest, carrying partially-consumed carcasses into riparian forests that fertilize vegetation and increase the production of scavenging insects (Schindler et al. 2003). If subsidies consist of diverse resource types, they can promote the co-existence of multiple consumers through resource partitioning (i.e., populations or species using a subset of the total resource pool), thus compartmentalizing a pulse into different food webs (Huxel et al. 2002). However, many studies aggregate consumer functional groups, which can prevent researchers from accurately quantifying subsidy effects (Marczak et al. 2007). Thus, a full understanding of the magnitude of subsidy effects necessitates the characterization of the response of individual consumer species.

Consumer responses to resource pulses are typically expected to be a function of the degree of specialization on the subsidy, the rate at which consumer populations can numerically respond, and the mobility of consumers (Otsfield and Kessing 2000, Marczak et al. 2007). Generalist consumers are often more efficient at exploiting pulsed prey, because of diet plasticity that allows generalists to quickly and effectively capitalize on newly-available resources (Ostfeld and Kessing 2000; Anderson et al. 2008; Yang 2005). Among generalist consumers, competition is expected to drive some asymmetry in the exploitation of pulsed production (Huxel et al. 2002; Baxter et al. 2005; Paetzold et 
al. 2005). Coexistence of generalist consumers, either within populations or across species, may not be stable if they both take advantage of similar resource opportunities (Chesson et al. 2004). Thus, diverse prey subsidies that present more foraging opportunities can benefit multiple consumers, having a stabilizing effect on communities (Huxel et al. 2002). Pulse diversity may be particularly important when resources are consumed by multiple taxa at upper trophic levels that can route pulsed production across ecosystem boundaries (Polis 1997). For instance, in Venezuelan llanos, relatively unproductive rivers are strongly subsidized by the annual drying of adjacent floodplains (Winemiller 1989). As prey pulse into river channels, multiple piscivorous fishes originating from both floodplains and river channels partition a diverse prey assemblage.

The effects of resource subsidies are typically pronounced in coastal and aquatic systems that are unproductive or have low levels of comparable resources (Polis et al. 1997; Fausch et al. 2002; Power and Dietrich 2002; Marczak et al. 2007). The Everglades are a rainfall-driven subtropical wetland, characterized by oligotrophy and phosphorous limitation (Gaiser et al. 2004; Ewe et al. 2006). At the southern end of the Everglades, graminoid freshwater marshes transition to an extensive mangrove-fringed estuary (Mclvor et al. 1994). These habitats have distinct fish communities, but patterns of fish abundance and distribution are strongly influenced by the same seasonal hydrological variation; which drives the extent of inundation and water levels in marshes, and salinity and tidal influence in the estuary (Chick et al. 2004; Trexler et al. 2005, Rehage and Loftus 2007). In the wet season, vast expanses of marshes become inundated, promoting secondary production and allowing smaller prey (i.e., cyprinodontoids and 
decapod crustaceans), as well as larger-bodied fishes (e.g., centrarchids) to disperse across the landscape. As rainfall decreases in the dry season, water levels drop and marshes dry, effectively reducing habitat availability and quality. In response to this seasonal drydown, fish and other aquatic organisms disperse to the deepest habitats in the landscape (i.e., solution and alligator holes, central sloughs and canals; Trexler et al. 2005; Rehage and Trexler 2006; Rehage and Loftus 2007; Parkos et al. 2011).

In the southern Everglades, freshwater fishes can take refuge into oligohaline tidal creeks as marshes dry (Rehage and Loftus 2007). Concentrations of marsh prey that enter the upper estuary also create a resource subsidy that consumers originating from estuarine, environments can exploit. For marsh taxa, movement into creeks may intensify predator prey interactions. However, the magnitude of the subsidy to estuarine food webs is unknown since estuarine consumers are forced to compete with freshwater species for marsh prey. Thus, the goals of this study were to: (1) characterize the diversity, duration and magnitude of the marsh prey pulse into the Everglades mangrove region, (2) examine the response of estuarine consumer abundance and diet to the subsidy, and (3) investigate the extent of resource partitioning among estuarine and freshwater consumers. I sampled prey abundance, predator numerical responses, and predator diets in mangrove creeks continuously before, during, and after a marsh prey subsidy. I hypothesized that in response to marsh drying and the prey pulse: (1) both marsh and estuarine consumers would increase in abundance and feeding activity, but (2) consumer specialization and thus partitioning would be high (3) As prey abundance and diversity decrease with pulse 
depletion, I expected feeding activity to decrease, and consumer diet overlap to increase, as consumers are forced to share a small pool of prey

\section{METHODS}

\section{Study System}

The Everglades are a karstic rainfall-driven subtropical wetland, where water flows across shallow vegetated freshwater marshes into an extensive region of tidal mangrove forests (dominated by red mangroves, Rhizophora mangle; Fry and Smith 2002). In the estuary, production is largely driven by marine phosphorous brought in by tides, storm events, and groundwater inputs, which causes the system to function as an 'upside down estuary', with higher productivity in the downstream portion of the system (Childers 2006; Ewe et al. 2006).

I sampled fishes in first and second order oligohaline ecotonal creeks in the southwestern region of Everglades National Park (ENP). These creeks link upstream freshwater marshes to the mangrove estuary (Figure 1; $25^{\circ} 27^{\prime} 28 \mathrm{~N}, 80^{\circ} 52^{\prime} 32 \mathrm{~W}$ ). In particular, this ecotonal region, known as Rookery Branch (RB), links the Shark River Slough (SRS), the main freshwater drainage for the southern Everglades, to the Shark River estuary (SRE). These two systems are a focal study area for the Florida Coastal Everglades Long-Term Ecological Research (FCE LTER, fce.lternet.edu). Previous work has shown that RB creeks and other oligohaline zones of the estuary function as drydown refugia for freshwater fishes (Rehage and Loftus 2007; McCarthy et al. 2011). Long-term marsh hydrology data (1986-2006) taken from USGS SH1 hydrostation (1.5 
$\mathrm{km}$ upstream of sites; http://sofia.usgs.gov/eden/) show that marshes in the vicinity of study creeks consistently dry between January and May. On average, marshes stay dry for $33 \pm 8$ days before re-flooding again at the onset of the wet season. During the dry season, as rainfall and freshwater inflows diminish, salinities in creeks peak at 11 PSU (Boucek and Rehage unpub. data), potentially limiting freshwater fishes to these uppermost reaches of the estuary.

\section{Focal Taxa}

To examine how consumers partition marsh prey subsidies in the upper SRE, I sampled the abundance and diets of two dominant freshwater marsh mesoconsumers; largemouth bass (Micropterus salmoides) and bowfin (Amia calva), and one estuarine consumer, snook (Centropomus undecimalis). Sampling over the past six years at these sites shows that these three species account for $45 \%( \pm 2.0 \mathrm{SE})$ of the yearly mesoconsumer abundance in RB creeks (Rehage et al.; unpub. data). Florida gar (Lepisosteus platyrhincus) are another dominant mesocosumer, accounting for $48 \%$ ( \pm 2.0 SE) of predator abundance. However, due to their high site fidelity (Heithaus et al. unpub. data), low feeding rates $(78 \% \pm 6.0 \mathrm{SE}$ of stomachs were empty, $\mathrm{n}=149$; Boucek and Rehage unpub. data), and potential gape limitations that would restrict them from sharing resources with focal consumers, I excluded gar from analyses presented here.

Although bass, bowfin, and snook co-occur at the ecotone, their physiological tolerances, habitat requirements, and foraging strategies differ. Snook are a tropical euryhaline ambush piscivore found throughout the Caribbean in habitats ranging from 
land-locked freshwater lakes to offshore reefs (Blewett et al. 2006; Muller and Taylor 2006; Adams et al. 2011). Largemouth bass and bowfin are mesopredators found throughout Everglades freshwater marshes, including natural (Chick et al. 2004; Trexler et al. 2005) and man-made habitats (e.g., canals; Rehage and Trexler 2006). Largemouth bass are a temperate cruising piscivore (Carey and Wahl 2010; Norris et al. 2010). Unlike snook, which tolerate a wide salinity range (Muller and Taylor 2006), largemouth bass are limited to salinities below 15 PSU, and often prefer salinities less than 3 PSU (Norris et al. 2010). Bowfin are a relic fish from the holostean lineage found throughout the Mississippi drainage, with wide tolerances to an array of abiotic conditions, except salinity (Scarnecchia 1992; Koch et al. 2009). Bowfin are cruising generalist predators, known to consume amphibious, invertebrate, and teleost prey in Everglades freshwater habitats (Loftus 2000; Jordan and Arrington 2001). Bowfin can tolerate salinities as high as 8 PSU, but experience mortality at 10 PSU (Hanson et al. 1976). Gapes are similar among the three consumers, thus no species should be restricted from consuming large prey items.

\section{Sampling Effort}

I sampled headwater creek shoreline and channel habitats at five fixed study sites in the RB region of SRE (Figure 1). Three of these sites were located at the upper most accessible reaches in first-order creeks, while two were located further downstream in the main stem of RB. These sites spanned the uppermost $3.2 \mathrm{~km}$ of the $25-\mathrm{km}$ SRE, and averaged $1.1 \pm 0.04 \mathrm{~m} \mathrm{SE}$ in depth. In order to capture variation in both prey and predator abundance, as well as predator diet in response to marsh drying, I sampled these 
five sites repeatedly, every three weeks between November 2010 and June 2011 (nine sampling events). I sampled invertebrate and cyprinodontoid abundance (typically $<4 \mathrm{~cm}$ in length) using unbaited 3-mm, metal-mesh minnow traps (25.4 mm opening). Minnow traps are a commonly used but often biased sampling technique (Rozas and Minello 1997; Layman and Smith 2001). To compensate for biases in catch due to trap placement, I deployed traps overnight in pairs, one at the water surface secured to mangrove proproots, and another set on the bottom. I randomly set five pairs of traps across a fixed $100 \mathrm{~m}$ stretch of shoreline at each site. Sampling via minnow trapping was conducted at all sampling events except January 2011. Fishes and macroinvertebrates captured in traps were fixed in $10 \%$ formalin and brought back to the lab for processing. I report minnow trap CPUE (catch per unit effort) as the sum of the overnight catches of the top and bottom trap.

In addition to traps, I sampled creeks using a boat-mounted, generator-powered electrofisher (two-anode, one cathode Smith-Root 9.0 unit) to target the larger prey and predator taxa (typically $4-75 \mathrm{~cm}$ in length). Boat electrofishing is an effective sampling technique in freshwater habitats, including the Everglades (Burkhardt and Gutreuter 1995, Chick et al. 1999), and has been used successfully to sample upper SRE fish communities (Rehage and Loftus 2007). Sampling was standardized by conducting 5 minute bouts (pedal time), and prior to analyses, CPUE was adjusted to a standardized length of shoreline (i.e., catches per $100 \mathrm{~m}$ ). I recorded the distance traveled during all bouts using a GPS unit, and then adjusted CPUE for distance ((CPUE/distance traveled)*100 m). For all bouts, power was standardized to 1500 Watts according to temperature and salinity conditions (Burkhardt and Gutreuter 1995). I conducted three 
replicate bouts at each site $(5$ sites $\times 3$ bouts $\times 9$ sampling events $=135$ electrofishing bouts). These replicate bouts were conducted at fixed points in each study creek, each $200 \mathrm{~m}$ apart. At the end of each bout, all captured fishes where counted, measured, and weighed.

I then removed stomach contents of focal consumers captured at each bout via nonlethal pulsed gastric lavage (PGL). Gastric lavage is an effective and relatively nonlethal method of removing ingested prey items (Brosse et al. 2002; Hakala and Johnson 2004; Barbour et al. in review). Pulsed gastric lavage removes stomach contents by using pressurized water from a tube inserted past the esophagus, causing regurgitation of consumed food items (Light et al. 1983; Hartleb and Moring, 1995; Fowler and Morris 2008). I repeated this procedure until three consecutive treatments failed to produce any new diet material. In snook and largemouth bass, PGL removes $100 \%$ of prey items (Hartleb and Moring 1995; Adams et al. 2009). I collected all stomach contents in a mesh screen, and fixed them in $10 \%$ formalin for later processing in the lab. I identified prey items in stomach samples by matching fish and invertebrate traits to a reference collection from study sites (e.g., spiny ray counts, body, gill raker, jaw, and pharyngeal teeth morphology, and scale type). Prey items that did not have at least three identifying features were recorded as 'unknown'. I weighed prey items separately, and reconstructed partially-digested prey items by matching tissue color, degree of digestion, and bone morphology in order to obtain accurate counts and length measurements. 


\section{Statistical Analyses}

I examined variation in consumer electrofishing CPUE and body size (standard length for bass and snook, and total length for bowfin) with two-way ANOVAs that tested the effects of species and time. For all analyses, I aggregated the nine sampling periods into four periods of interest (hereafter referred to as seasons): wet (four sampling events: November to February), early transition (early March sample), late transition (late March sample) and dry (three sampling events: April to June 2011). From electrofishing, I obtained CPUE of all sunfishes, a key prey item in consumer diets, and compared CPUE across sites and sampling periods with a 2-way ANOVA. Sunfish and predator CPUE are reported as the number of individuals caught per 100 meters of creek shoreline. For prey caught in minnow traps, I report the sum of the top and bottom overnight catch, and aggregated these into two key functional groups: cyprinodontoids and invertebrate prey. A three-way ANOVA was used to examine the effects of season, functional group, and site on total CPUE of minnow trap pairs. To meet parametric test assumptions, I log transformed all CPUEs prior to analyses (Ln (CPUE+1)), and used Tukey's pairwise comparisons in post hoc tests.

I report numerical values for all dietary analyses. Gravimetric measures were excluded since they often overestimate the importance of any single, large prey item (Hyslop 1980; Cortés 1997). Numerical counts were converted into proportional contributions to each individual's diet during any one season. Consumed fishes that were not readily identifiable passed the level of 'unknown fish' were excluded from analyses (accounting for $30 \%$ of diet items), which is comparable to previous diet studies conducted on piscivorous fishes (Jepsen et al. 1997; Blewett et al. 2006; Adams et al. 
2009). I calculated two dietary metrics of interest: proportion of full stomachs per bout and numerical proportions of cyprinodontoids, invertebrates, and sunfishes found in diet samples. Because of nonnormality, I used Scheirer-Ray-Hare tests (equivalent to 2-way ANOVAs) to examine the effects of consumer species and season on the proportion of full stomachs, and the numerical proportions of cyprinidontoids, invertebrates, and sunfishes in diets. This test has been used in other diet studies, although it is often criticized for being relatively conservative (Dytham 1999; Meynier et al. 2008). I used Mann-Whitney U tests in post hoc comparisons (Meynier et al. 2008), and SASC 9.2 for all statistical analyses.

\section{RESULTS}

\section{Pulse Dynamics: Small Prey}

From November 2010 to June 2011, I collected 9744 fishes and macroinvertebrates (22 fish species and 5 invertebrate taxa) in minnow traps. Fish CPUE in trap pairs was dominated by bluefin killifish (Lucania goodei, 71\%) and Eastern mosquitofish (Gambusia holbrooki, 24\%), while the remaining 5\% consisted of Florida flagfish (Jordanella floridae), gobies (Gobiosoma spp), and sailfin mollies (Poecilia latipinna). Of the invertebrates caught in traps, $99 \%$ were palaemonid shrimp (Palaemonetes spp), likely dominated by Palaemonetes paludosus (McCarthy et al. 2011). During the wet season, catches were relatively low, averaging 2.9 fish and 1.5 macroinvertebrates per trap pair. Once marshes upstream of the RB dried in mid-March (March $15^{\text {th }}, 2011$ for SH1, Figure 2A), There was a significant increase in both prey 
groups $(\mathrm{p}<0.011)$. Cyprinodontoids increased seven fold, while invertebrates showed a threefold increased (Table 1; Figure 2A). Increases in both cyprinodontoids and invertebrates within the estuary were relatively short-lived, lasting only six weeks. By the dry season sample, the abundance of small fishes and shrimp in creeks were significantly lower than during the wet season $(\mathrm{p}<0.05)$.

\section{Sunfish Prey and Consumer CPUE}

I sampled a total of 2755 fish from 25 species over the course of the nine sampling events. Of these 25 taxa, 19 were considered potential prey items due to their smaller size. Among these prey taxa, $72 \%$ were sunfishes, dominated by dollar (Lepomis marginatus) and spotted sunfishes (Lepomis punctatus). Estuarine taxa accounted for the reminder of the prey component: $8 \%$ were hogchokers (Trinectes maculatus), $6 \%$ striped mullet (Mugil cephalus), 5\% striped mojarra (Diapterus plumieri), and 4\% ladyfish (Elops saurus). For the sunfishes, CPUE averaged only 0.8 fish per $100 \mathrm{~m}$ of mangrove shoreline during the wet season, but their abundance increased 6.5 fold in the early and late transition sampling events, matching the timing of marsh drying (Table 1; Figure 2B). Sunfish numbers appeared to show a sharper decrease than the smaller prey, with their numbers dropping from 23 to 7 fish per $100 \mathrm{~m}$ of creek shoreline within a threeweek period (Late transition vs. dry, $\mathrm{p}=0.0001$; Figure $2 \mathrm{~B}$ ).

The three focal species in this study composed $60 \%$ of predator catches: $37 \%$ were largemouth bass, $14 \%$ were bowfin, and $9 \%$ were snook. Gar dominated the remainder of predator catches (39\%). Across seasons, bass and bowfin numbers increased 
by 8 and 32 fold respectively between the wet and early transition samples, matching the timing of marsh drying and the prey pulse ( $\mathrm{p}<0.001$; Figure $2 \mathrm{~B})$. In contrast, snook numbers lagged behind, increasing from 0.3 to 2.5 fish per $100 \mathrm{~m}$ of shoreline between the wet and late transition samples $(p=0.014$, Figure $2 B)$. On average, snook numbers in the late transition season were comparable to bowfin numbers ( 3 fish per $100 \mathrm{~m}$ ), but significantly lower than bass numbers (11 fish per $100 \mathrm{~m} ; \mathrm{p}<0.001$ ).

\section{Stomach Contents}

I lavaged every snook and bowfin captured in electrofishing samples $(n=99$ and 159 , respectively), and approximately half of the largemouth bass captured (247 out of 571 bass caught). Proportions of stomachs with prey among these three consumers did not vary between the wet and transition seasons $(\mathrm{p}>0.095)$, but decreased significantly as resources depleted in the dry season $(\mathrm{p}<0.004)$. Across bowfin, bass, and snook, stomach fullness decreased from $83 \%$ in the early transition season to $43 \%$ in the dry season sample (Figure 4; Table 2).

Overall, freshwater prey taxa, presumably of marsh origin, composed $93 \%$ of all diet items. In the wet season, marsh invertebrates dominated diets of all consumers, accounting for $65 \%$ of prey items, while small fishes and sunfishes contributed relatively little $(<15 \%$ for each group). As marshes dried in the early transition season and fish prey became more abundant in the estuary, consumers began eating more cyprinodontoids ( $33 \%$ of prey items; Figure $5 \mathrm{~A}$ ), and sunfishes $(41 \% ; \mathrm{p}<0.040$; Figure 5B). During the late transition season, consumption of cyprinodontoids remained high 
( $40 \%$ of prey items), but sunfishes in diets decreased to $12 \%$ of prey items consumed $(\mathrm{p}=$ 0.002). For invertebrates, consumption was minimal during the early transition season ( $24 \%$ of prey items), but increased in subsequent samples ( $43 \%$ in the late transition and $60 \%$ of prey items in the dry season; Figure $5 \mathrm{C}$ ).

The consumption of cyprinodontoids and invertebrates varied across consumer taxa, but this contribution was not affected by season (Table 2). Across sampling periods, bass consistently consumed a greater proportion of cyprinodontoids than both snook and bowfin ( $40 \%$ vs. $19 \%$ and $16.5 \%$ of prey items respectively; p $<0.042$; Figure $5 \mathrm{~A}$ ). Instead, invertebrates contributed more to bowfin diets ( $68 \%$ of prey items compared to $49 \%$ for snook and $42 \%$ for bass, $\mathrm{p}<0.058$; Figure $5 \mathrm{~B}$ ). Sunfish consumption varied both across seasons and consumer species (Table 2; Figure 5C). In the early transition season when sunfish abundance increased, snook consumed more sunfishes relative to the other two species $(80 \%$ of prey items vs. an average of $28 \%$ for the freshwater consumers; $\mathrm{p}<0.020$; Figure $5 \mathrm{C}$ ). But, consumption of sunfishes by snook decreased dramatically in the late transition season to $17 \%$ of prey items, which was similar to the amount consumed by bass $(16 \% ; \mathrm{p}=0.081)$, but higher than the $1 \%$ consumed by bowfin $(p=0.039)$. Lastly during the dry season, snook continued to eat more sunfishes, at least relative to bowfin ( $15 \%$ vs. $3 \%, p=0.018$; Figure $5 \mathrm{C})$.

\section{DISCUSSION}

Although pulsed subsidies account for a significant portion of resource availability in many systems, studies often overlook how functionally-similar consumer species respond to resource pulses (Marczak et al. 2007). Yang et al. (2008) noted the 
need to consider pulsed subsidies from the perspective of the consumer. Thus, it is important to not only identify the bulk amount of pulsed resources consumed, but how it is routed through specific consumer taxa. In this study, I identified a hydrologicallydriven allochthonous prey pulse that was partitioned among three consumers within the oligohaline zone of an Everglades estuary. Influxes of prey into the mangrove region may be extremely important, since estuarine prey made up only $7 \%$ of the diets across all consumers. Heavy reliance on allochthonous subsidies by consumers has been shown in other coastal and aquatic studies (Marczak et al. 2007). For instance, Paetzold et al. (2005) noted that $89 \%$ of terrestrial carabid beetle diets were derived from pulsed emergences of aquatic stream insects.

Dietary analyses showed that the marsh prey subsidy was significantly partitioned among the three focal consumers. At peak prey abundance, largemouth bass primarily consumed smaller-bodied cyprinodontoids, bowfin diets were dominated by invertebrates (most notably palaemonid shrimp), and snook almost exclusively consumed the larger sunfishes. Differential resource use by consumers during pulsed events can have important ecological ramifications, especially if consumers are long-lived and highly mobile, and thus able to transport pulsed production across ecosystem boundaries (Polis et al. 1997). In this study, snook likely exported marsh production to the mid and lower estuary and potentially to marine habitats, while bass and bowfin routed it back to marshes upon reflooding. If these highly abundant and ephemeral resource pulses occur in some predictable fashion, long-lived consumers may track them, potentially creating predictable, energetic linkages across ecosystems boundaries (Polis 1997; e.g., Rosenblatt 
and Heithaus 2011). These pulses of high resource availability may be particularly important for fishes, which have oversized stomachs relative to body size, likely an evolutionary response to high temporal resource heterogeneity (Armstrong and Schindler 2011).

Previous work shows that resource pulses are often met by two types of consumers, opportunistic residents and mobile specialists (Yang et al. 2008). Opportunistic residents are local generalist consumers that rapidly respond to pulsed resources (Watt et al. 2000; Spiller et al. 2010), whereas mobile specialists actively track patchy and asynchronous prey (Yang et al. 2008). Snook may be considered mobile specialists that move upstream for a short period of time to exploit sunfishes, this may be particularly true for larger individuals. Like snook, speckled peacock bass (Cichla temensis) move down the Cinaruco River during falling water periods to take advantage of pulses of floodplain S. kneri prey (Hoeinghaus et al. 2003). As sunfish abundance dropped, snook abundance remained the same, but mean size in study creeks decreased, indicating a replacement of adult snook by smaller conspecifics. Adult snook have been shown to cannibalize smaller juvenile and subadults elsewhere (Adams et al. 2006). Thus, smaller snook may not move into the Rookery Branch during the peak of the pulse in order to avoid predation.

In other Florida rivers, such as the Peace and Caloosahatchee, snook leave oligohaline systems in the spring and early summer likely to spawn at the coast (Blewett et al. 2009). . Adams et al. (2011) showed significant site fidelity by snook in spawning grounds in Charlotte Harbor, but whether they express similar site fidelity in the context 
of foraging is unknown. Ongoing tagging work aims to examine if snook repeatedly return to Everglades headwater creeks to take advantage of seasonal prey subsidies. In contrast, bowfin and bass were displaced from marshes as a result of seasonal dry down. Thus, the degree to which they are actively tracking the pulse is unknown, but it is plausible that they experience higher foraging success in mangrove creeks relative to the more complex, vegetated marshes. Habitat complexity is often negatively related to foraging efficiency; particularly for piscivorous taxa such as bass (Valley and Bremigan 2002).

Overall, snook abundance in 2010-2011 was relatively low compare to previous years, when snook numbers during marsh drying were similar those of bowfin (R.E. Boucek, unpub. data). These low numbers are likely the result of an episodic cold event that killed approximately $80 \%$ of snook in southwest Florida during winter of 2010 (A. Adams, unpub. data). Cold fronts can occur from September to April, dropping water temperatures below lethal limits $\left(9-14^{\circ} \mathrm{C}\right.$; Muller and Taylor 2006). During sampling, snook were absent from study sites in December 2010 and February 2011, when water temperatures reached $12.5^{\circ} \mathrm{C}$. Cold fronts may alter snook distribution away from RB and to warmer waters downstream, resulting in short periods of predator release for sunfish prey. Thus, temperature has the potential to strongly mediate the degree to which this pulse contributes to snook foraging and overall population performance, not unlike its overwhelming effect on other ecological processes (Gilman et al. 2010). With climate change predicted to increase the frequency and intensity of cold events in South Florida 
(Noss et al. 2011), the routing of energy across marsh and estuarine compartments of the system may be altered.

The mechanism by which snook detect and track the pulse is not known. The fact that their increases in abundance are slightly delayed to those of marsh consumers suggest that cues may be involved. One possibility is that snook rely on general cues that are correlated with the prey pulse, such as increase salinity (e.g., Orrock et al. 2004). Else, snook may routinely sample the upper estuary to determine prey abundance. Future work that tracks consumer movements across the estuary will help understand the mechanisms underlying prey pulse detection.

Although there was no significant increase in feeding activity in response to the marsh prey pulse, consumer diets shifted at the onset of marsh drying. Bass and snook shifted from consuming primarily invertebrates during the wet season to strictly piscivorous diets. However, bass consumed the smaller cyprinodontoids, while snook consumed the larger sunfishes. Although bowfin did not incorporate more fish into their diets, they consumed more marsh invertebrates. Thus, consumers are partitioning this relatively diverse pulse (Huxel et al. 2002), but snook may be receiving the most energetic gain from the pulse, since sunfishes are substantially larger $(>6 \mathrm{~cm} \mathrm{SL})$ and likely provide more energy per prey unit (Thierry et al. 2011). Resource partitioning in Venezuelan rivers shows that among three Cichla spp., C. temensis targets significantly larger prey than $C$. orinocensis and $C$. intermedia, and as a result, is the only one to see a fitness gain (Jepsen et al. 1997; Hoeinghaus et al. 2006). 
Diets frequently include prey that consumers are most efficient at capturing, not necessarily those that provide the most energetic gain relative to handling time (i.e., optimal diet theory), nor the ones that are most often attacked (i.e., 'active predator choice'; Sih and Christensen 2001). Therefore, consumer prey 'preferences' reflect capture success that is strongly influenced by prey behavior (e.g., refuge use and mobility). Antipredator behavioral tactics affect predator-prey habitat domain overlap, encounter rates, and escape responses (Sih and Christensen 2001; Schmitz 2007). For instance, cyprinodontoids dominated bass diets relative to other prey. Bass are relatively smaller visual predators that may occupy and successfully forage in shallower littoral zones that are inhabited by these smaller-bodied prey (Chick and Mclvor 1997). Snook, as the largest predator, may be better at capturing and handling large sunfish prey. Also snook are relatively mobile (Muller and Taylor 2006), thus may be better at tracking high sunfish patchiness across the landscape (Mundahl et al. 1997). Compared to bass and snook, bowfin are benthic foragers that prefer turbid waters and structurally complex habitats (Koch et al. 2009). Consequently, their ability to detect and capture invertebrates hidden within the substrate or embedded in matrices of prop roots ,may be higher. Although prey behaviors and consumer foraging styles strongly influence predator 'preference', other factors such as competition and predation may also affect consumer diets (Schmitz 2007).

Overall, seasonal marsh hydrology effectively created a resource pulse that subsidized and concentrated large-bodied predatory fishes in an upper Everglades estuary. The diversity of the pulse provided foraging opportunities that wereexploited by 
multiple consumers with different foraging tactics, thus routing pulsed production through multiple pathways and across ecosystem boundaries. Understanding and conserving complex trophic pathways within estuaries and coastal systems is of particular importance, since they can play a vital role in the provisioning of ecosystem services (e.g., fisheries; Worm et al. 2006). Further, resource pulses have been shown to allow for the coexistence of multiple consumer species, through increased trophic diversity, ultimately promoting system resilience (Fausch et al. 2007). In many estuaries, hydrological patterns have been altered to accommodate water and land use demands, resulting in the simplification of food webs (Adams et al. 2009; Layman et al. 2007). Climate change may have a similar effect. Thus, identifying these trophic linkages, and understanding their context-dependency, and implications for ecosystem function and service provisioning is of critical importance, and may prove helpful in successful resource management. 
TABLE 1. Summary of ANOVAs, testing effects of season (S), taxonomic group (T), and site (C) on estimates of prey abundance from minnow traps and electrofishing, and of predator abundance and size, also from electrofishing bouts.

\begin{tabular}{|c|c|c|c|c|c|c|c|c|c|c|c|c|}
\hline \multirow[b]{2}{*}{ Effects } & \multirow[b]{2}{*}{$\mathrm{df}$} & \multicolumn{2}{|c|}{$\begin{array}{l}\text { Minnow trap } \\
\text { CPUE }\end{array}$} & \multicolumn{3}{|c|}{ Sunfish CPUE } & \multicolumn{3}{|c|}{ Predator CPUE } & \multicolumn{3}{|c|}{ Predator size (length) } \\
\hline & & $\mathrm{F}$ & $\mathrm{p}$ & $\mathrm{df}$ & $\mathrm{F}$ & $\mathrm{p}$ & $\mathrm{df}$ & $\mathrm{F}$ & $\mathrm{p}$ & $\mathrm{df}$ & $\mathrm{F}$ & $\mathrm{p}$ \\
\hline PS & 3,272 & 27.0 & $<0.001$ & 3,114 & 49.7 & $<0.001$ & 3,423 & 49.5 & $<0.001$ & 3,930 & 4.9 & 0.002 \\
\hline $\mathrm{T}$ & 1,272 & 29.0 & $<0.001$ & & & & 3,423 & 64.2 & $<0.001$ & 2,930 & 583.9 & $<0.001$ \\
\hline $\mathrm{C}$ & 3,272 & 9.1 & $<0.001$ & 4,114 & 3.8 & 0.006 & & & & & & \\
\hline $\mathrm{T} \times \mathrm{S}$ & 3,272 & 13.0 & $<0.001$ & & & & 6,423 & 4.0 & $<0.001$ & 6,930 & 10.6 & $<0.001$ \\
\hline $\mathrm{C} \times \mathrm{S}$ & 12,272 & 1.3 & 0.207 & 12,114 & 2.6 & 0.004 & & & & & & \\
\hline $\mathrm{CxT}$ & 4,272 & 3.3 & 0.011 & & & & & & & & & \\
\hline $\mathrm{C} \times \mathrm{T} \times \mathrm{S}$ & 12,272 & 0.9 & 0.504 & & & & & & & & & \\
\hline
\end{tabular}


TABLE 2. Results of Scheier-Ray-Hare tests comparing effects of species and season on mean proportion of full stomachs (FS) and mean numerical counts of the three prey types, cyprinodontoids (C), invertebrates (I), and sunfishes (S), compared. Significant statistical values are shown in bold.

\begin{tabular}{cccccccccc} 
Diet & \multicolumn{2}{c}{ Season } & \multicolumn{3}{c}{ Predator species } & \multicolumn{3}{c}{ Season x species } \\
variable & $d f$ & $F$ & $P$ & $d f$ & $F$ & $P$ & $d f$ & $F$ & $P$ \\
\hline FS & 3,189 & 14.5 & $<\mathbf{0 . 0 0 1}$ & 2,189 & 0.4 & 0.810 & 6,189 & 0.8 & 0.990 \\
C & 3,273 & 17.0 & $<\mathbf{0 . 0 0 1}$ & 2,273 & 36.5 & $<.001$ & 6,273 & 5.6 & 0.470 \\
I & 3,273 & 9.5 & $<\mathbf{0 . 0 2 4}$ & 2,273 & $11.1<.001$ & 6,273 & 2.7 & 0.850 \\
S & 3,273 & 40.0 & $<\mathbf{0 . 0 0 1}$ & 2,273 & $12.9<\mathbf{0 0 1}$ & 6,273 & 17.7 & $\mathbf{0 . 0 1 0}$ \\
\hline
\end{tabular}




\section{FIGURE 1}

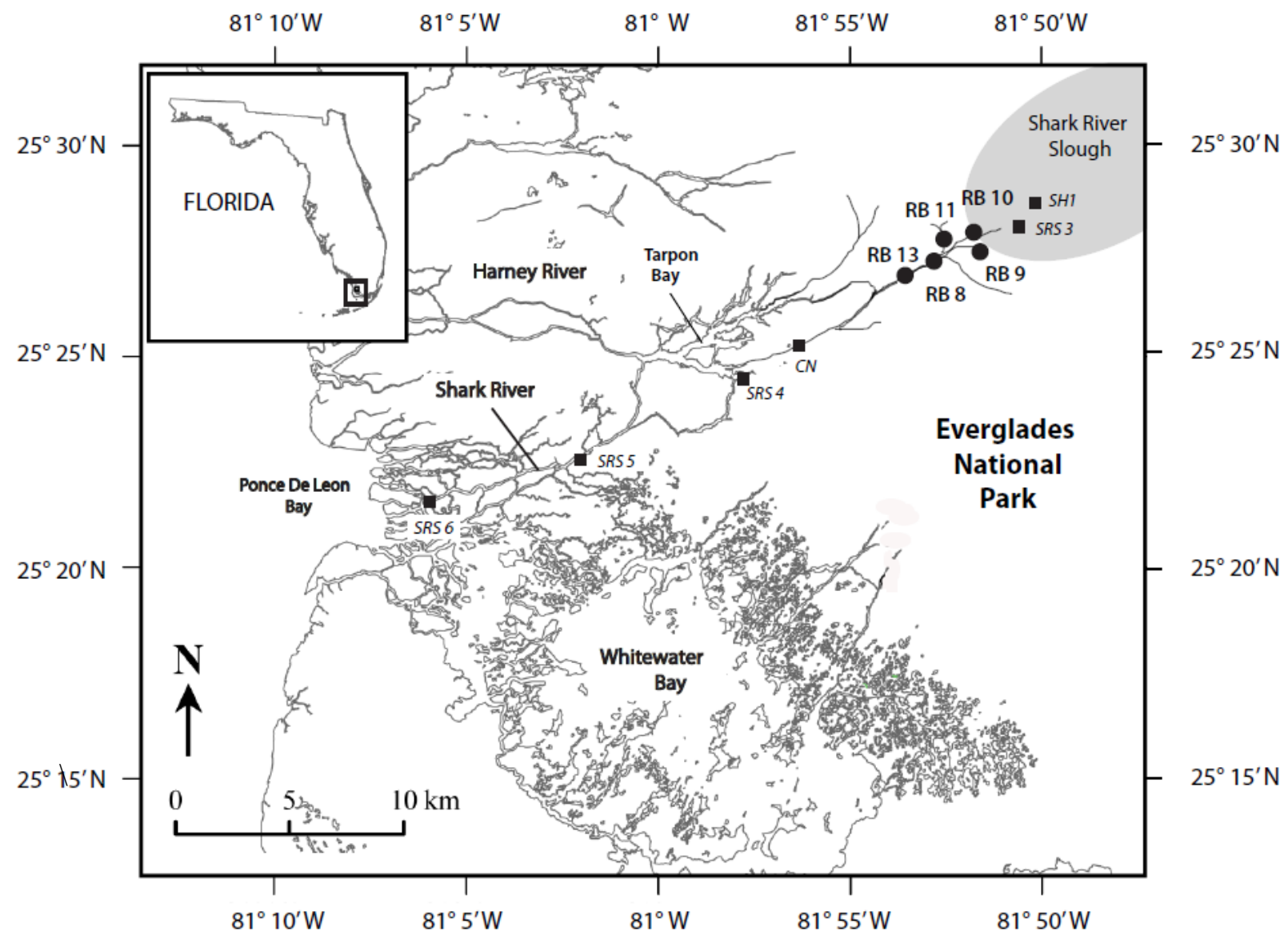


FIGURE 2
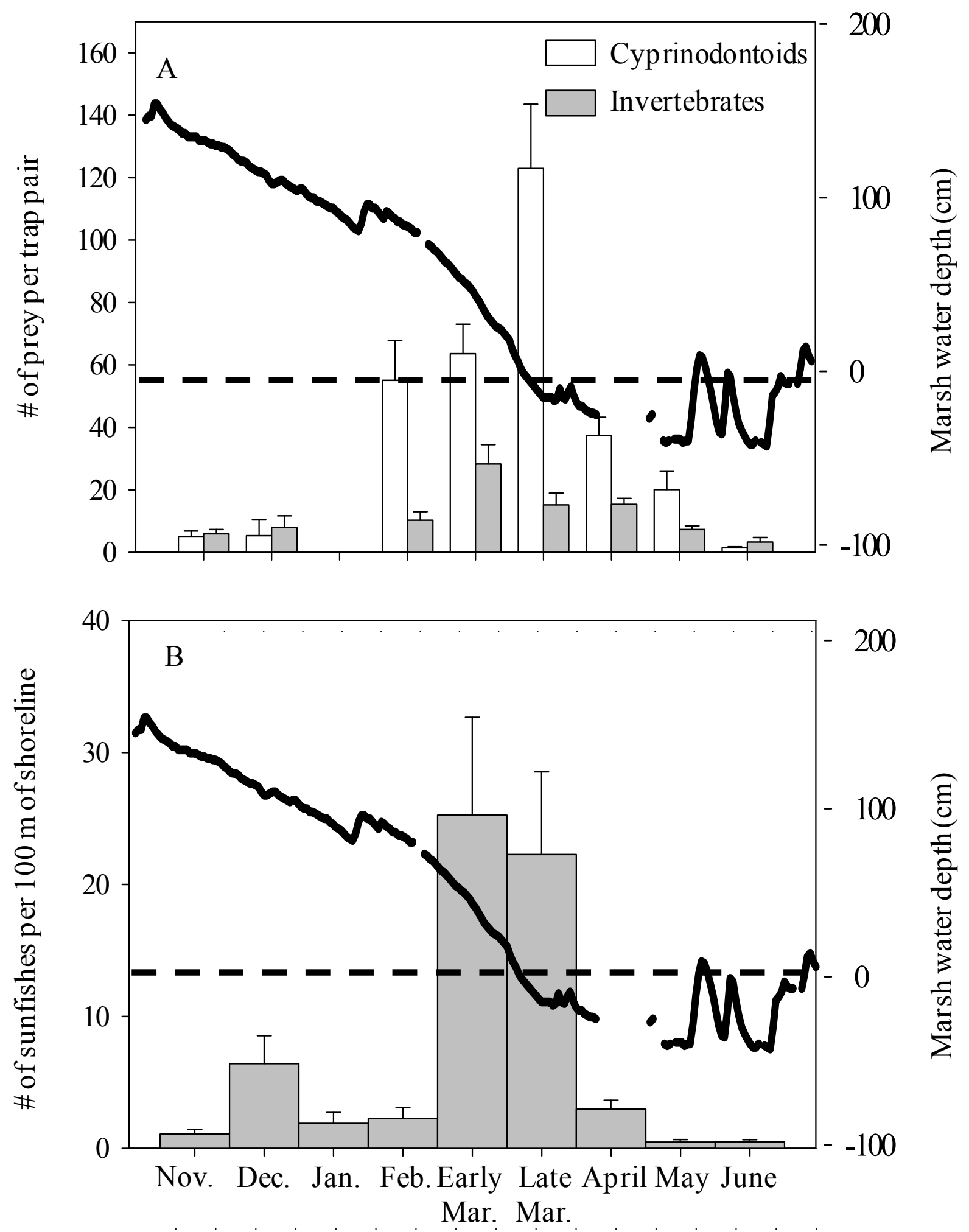
FIGURE 3
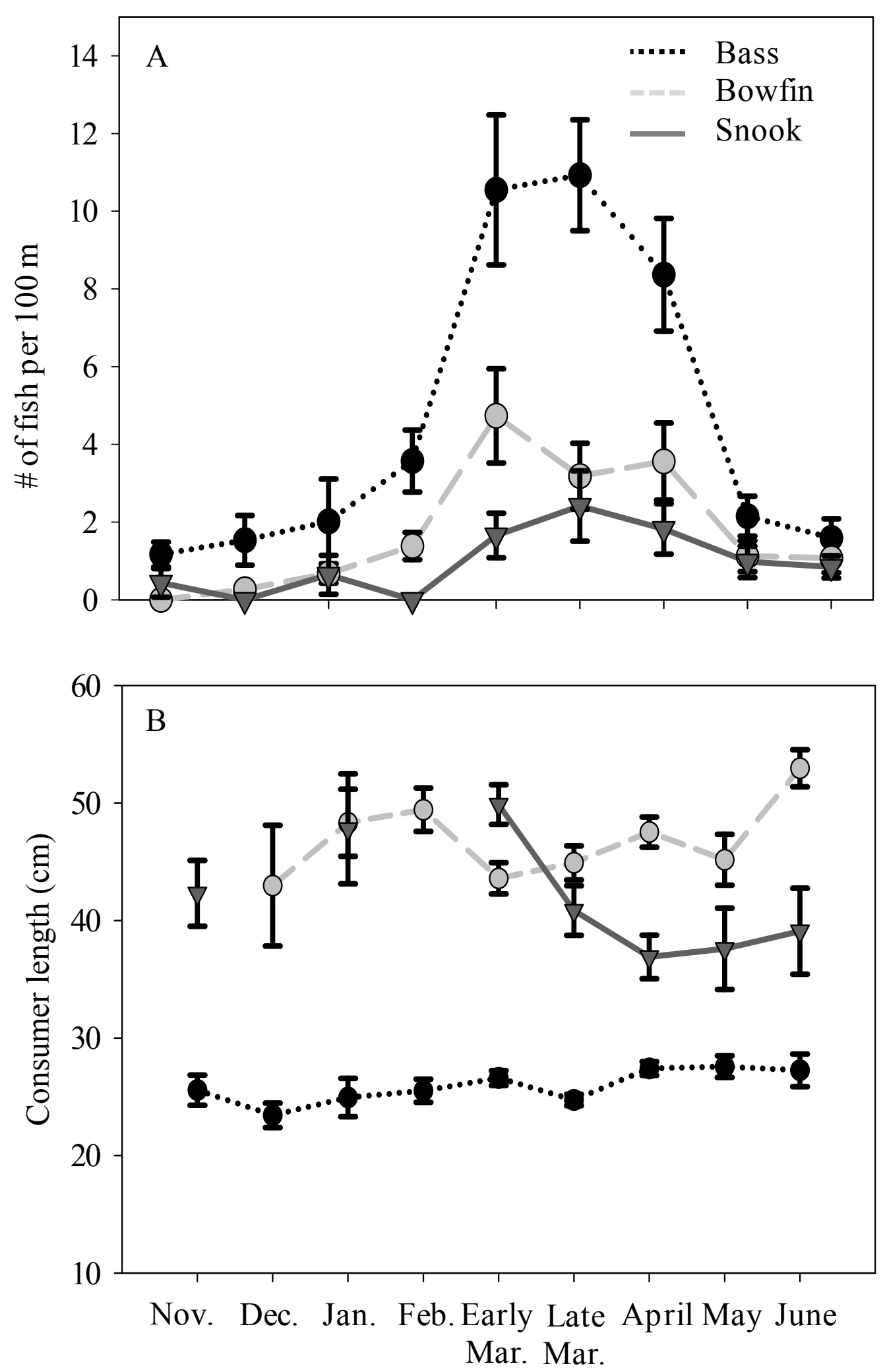


\section{FIGURE 4}

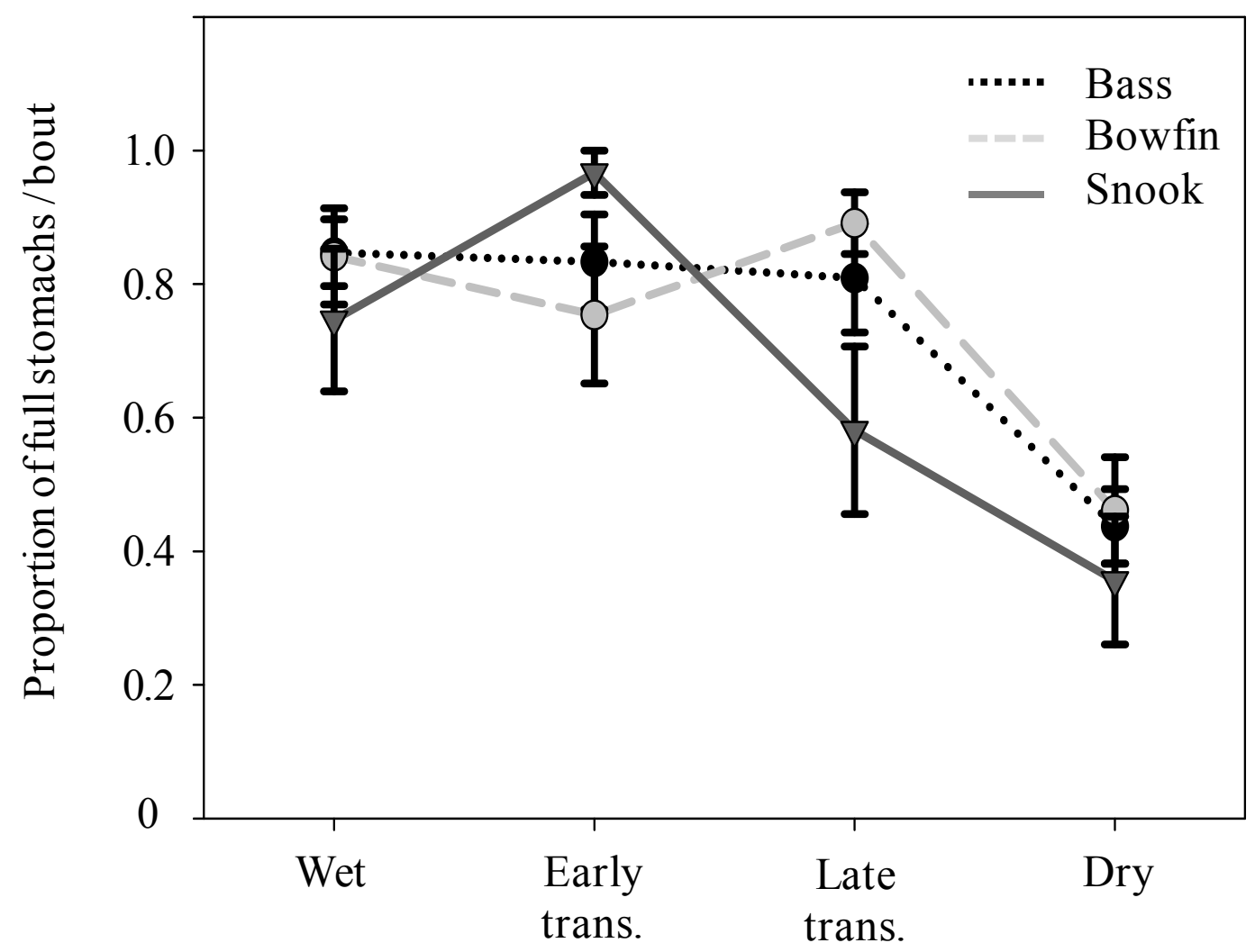


FIGURE 5

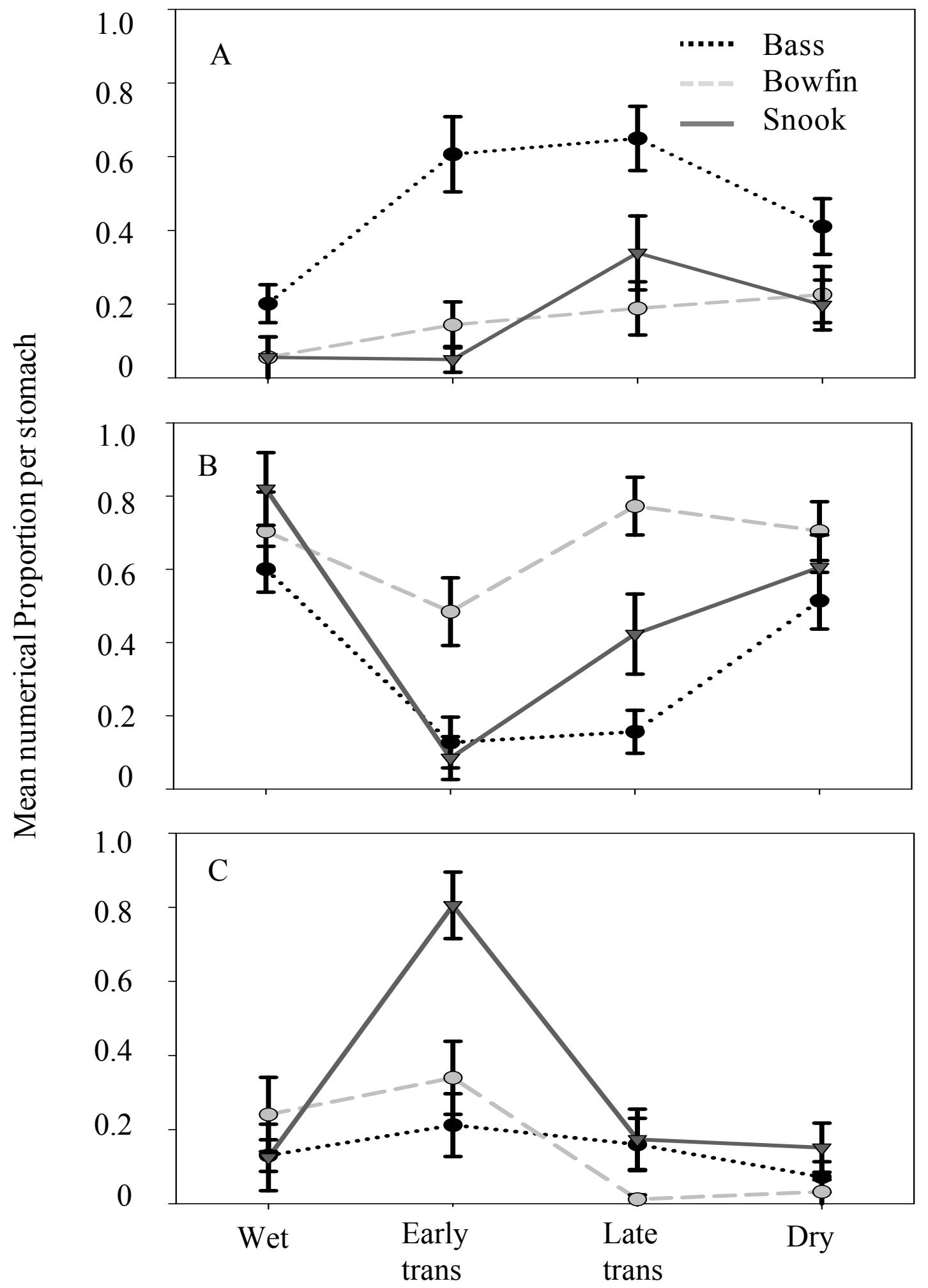




\section{REFERENCES}

Adams, AJ, Wolfe RK (2006). Cannibalism of juveniles by adult common snook (Centropomus undecimalis). Gulf Mexico Science 24: 11-13.

Adams AJ, Wolfe RK, Layman CA (2009) Preliminary examination of how human driven freshwater flow alteration affects trophic ecology of juvenile snook (Centropomus undecimalis) in estuarine creeks Estuaries and Coasts 32:819-828

Adams AJ, Hill JE, Samoray C (2011) Characteristics of spawning ground fidelity by a diadromous fish: a multi-year perspective Environmental Biology of Fishes DOI: $10.1007 / \mathrm{s} 10641-011-9851$

Anderson, WB, Wait DA, Stapp P (2008) Resources from another place and time: responses to pulses in a spatially subsidized system. Ecology 89:660-670.

Armstrong JB, Schindler DE (2011) Excess digestive capacity in predators reflects a life of feast and famine. Nature doi:10.1038

Barbour AB, Boucek RB, Adams AJ (In Review) Evaluation of pulsed gastric lavage on apparent survival of a juvenile fish in a natural system. Journal of Experimental Biology.

Baxter CV, Rausch KD, Saunders WC (2005) Tangled webs: reciprocal flows of invertebrate prey link streams and riparian zones. Freshwater Biology 50:201-220

Blewett DA, Hensley RA, Stevens PW (2006) Feeding habits of Common Snook, Centropomus undecdimalis, in Charlotte Harbor Florida. Gulf and Caarribbean Research 18:1-13

Blewett DA, Stevens PW, Champeau TR, Taylor RG (2009) Use of rivers by common snook Centropomus undecimalis in southwest Florida: A first step in addressing the overwintering paradigm. Biological Sciences 72:310-324

Brosse L, Dumont P, Lepage M, Rochard E, (2002) Evaluation of a gastric lavage method for sturgeons. North American Journal of Fisheries Management 22: 955-960.

Burkhardt R, Gutreuter S (1995) Improving electrofishing catch consistency by standardizing power. North American Journal of Fisheries Management 15:375-381

Carey M, Wahl D (2010) Interactions of multiple predators with different foraging modes in an aquatic food web. Oecologia 162:443-452

Chesson P (2000) Mechanisms of maintenance of species diversity. Annual Reviews of Ecology and Ecosystems 31:343-366 
Chesson P, Gebauer RLE, Schwinning S, Huntly N, Wiegand K, Ernest MSK Sher A, Novoplansky A, Weltzin JF(2004) Resource pulses, species interactions, and diversity maintenance in arid and semi-arid environments. Oecologia 141:236-253.

Chick JH, McIvor CC (1997) Habitat selection by three littoral zone fishes: effects of predation pressure, plant density, and macrophyte type. Ecology of Freshwater Fish $6: 27-35$.

Chick J, Coyne H, Trexler J (1999) Effectiveness of airboat electrofishing for sampling fishes in shallow vegetated habitats. North American Journal of Fisheries Management 19:957-967

Chick JH, Ruetz CR, Trexler JC (2004) Spatial scale and abundance patterns of large fish communities in freshwater marshes of the Florida Everglades. Wetlands 24:652-664.

Childers DL (2006) A synthesis of long-term research by the Florida Coastal Everglades LTER program. Hydrobiologia 569:531-544.

Dytham C (1999) Choosing and using statistics: a biologist's guide. Blackwell Science, Oxford

Ewe SML, Gaiser EE, Childers DL, Iwaniec D, Rivera-Monroy VH, Twilley RR (2006) Spatial and temporal patterns of aboveground net primary productivity (ANPP) along two freshwater-estuarine transects in the Florida Coastal Everglades. Hydrobiologia 569: 459-474

Fausch KD, Power ME, Murakami M (2002) Linkages between stream and forest food webs: Shigeru Nakano's legacy for ecology in Japan. Trends in Ecology and Evolution $17: 429-434$.

Finke DL, Snyder WE(2008) Niche partitioning increases resource exploitation by diverse communities. Science 321:1488-1489.

Fry D, Smith TJ (2002) Stable isotope studies of red mangroves and filter feeders from the Shark River estuary, Florida. Bulletin of Marine Science 70:871-890

Fowler AL, Morris JE, (2008). A new stomach sample collection device for fish gastric lavage samples. American Journal of Fisheries Management. 28: 1775-1778.

Gaiser EE, Scinto LJ, Richards JH, Jayachandran K, Childers DL, Trexler JC, Jones RD (2004) Phosphorus in periphyton mats provides the best metric for detecting low-level P enrichment in an oligotrophic wetland. Water Research 38:507-516 
Gilman SE, Urban MC, Tweksbur J, Gilchrist GW, Holt RD (2010) A framework for community interactions under climate change. TREE 25:325-331.

Hakala JP, Johnson FD (2004) Evaluation of a gastric lavage method for use on largemouth bass. North American Journal of Fisheries Management 24: 1398-1403.

Hartleb CF, Moring JR (1995). An improved gastric lavage device for removing stomach contents from live fish. Fisheries Research 24: 261-265

Hanson RC, Duff D, Brehe J, Fleming WR (1976) The effect of various salinities, hypophysectomy, and hormone treatments on the survival and sodium and potassium content of juvenile bowfin, Amia calva. Physiological Zoology 49:376-385

Hoeinghaus DJ, Layman CA, Arrington DA, Winemiller KO (2003). Movement of Cichla species (Cichlidae) in a Venezuelan floodplain river. Neotropical Ichthyology $1: 121-126$.

Hoeinghaus DJ, Winemiller KO, Layman CA, Arrington DA, DB Jespen (2006) Effects of seasonality and migratory prey on body condition of Cichla species in a tropical floodplain river. Ecology of Freshwater Fish doi: 10.1111/j.1600-0633.2006.00152.x

Holt RD, (2008) Theoretical perspectives on resource pulses. Ecology 89:671-681.

Huxel GR, McCann K (1998) Food web stability: the influence of trophic flows across habitats. American Naturalist 152: 460-469.

Huxel GR, McCann K, Polis GA (2002) Effects of partitioning allochthonous and autochthonous resources on foob web stability. Ecological Research 17 419-432.

Hyslop EJ (1980) Stomach contents analysis-a review of methods and their application. Journal of Fish Biology 17: 411-429.

Jepsen DB, Winemiller KO, Taphorn DC (1997) Temporal patterns of resource partitioning among Cichla species in a Venezuelan blackwater river. Journal of Fish Biology 51:1085-1108

Jordan F, Arrington DA (2001) Weak trophic interactions between large predatory fishes and herpetofauna in the channelized Kissimmee River, Florida, USA. Wetlands 21155 159.

Koch JD, Quist MC, Hansen KA, Jones GA (2009) Population dynamics and potential management of bowfin (Amia calva) in the upper Mississippi River. Journal of Applied Ichthyology 25:545-550 
Layman CA, Smith DE (2001) Sampling bias of minnow traps in shallow aquatic habitats on the eastern shore of Virginia. Wetlands 21: 145-154

Layman CA, Quattrochi JP, Peyer CM, Allgeier JE (2007) Niche width collapse in a resilient top predator following ecosystem fragmentation. Ecology Letters 10:937-944.

Light W, Adler H, Arnold DE, (1983) Evaluation of gastric lavage for stomach analyses. North American Journal of Fisheries Management 3: 81-85.

Loftus WF (2000) Accumulation and fate of mercury in an Everglades aquatic food web. PhD dissertation, Florida International University, Miami, Florida.

Marczak LB, Thompson RM, Richardson JS (2007) Meta-analysis: trophic level, habitat and productivity shape the food web effects of resource subsidies. Ecology 88:140-148

McCarthy LC, Rehage JS, Loftus WT (2011) Species segregation, trophic function and isotopic niche breadth in palaemonid shrimp along a subtropical estuary. Bulletin of Marine Science, accepted with revisions.

Mclvor C, Ley J, Bjork R (1994) Changes in freshwater inflow from the Everglades to $M$ Florida Bay including effects on biota and biotic processes: a review., Vol. St. Lucie $M$ Press, Delray Beach.

Meynier L, Pusineri C, Spitz J, Begoña Santos M, Pierce GJ, Ridoux V (2007) Intraspecific dietary variation in the short-beaked common dolphin Delphinus delphis in the Bay of Biscay: importance of flatfish. Marine Ecology Progress Series 354:277278

Muller RG, Taylor RG (2006) The 2005 stock assessment unpdate of common snook, Centropomus undecimalis, Fish and Wildlife Research Institute

Mundahl ND, Melnytschuk C, Spielman DK, Harkins JP, Funk K, Bilicki AM (1998) Effectiveness of bowfin as a predator on bluegill in a vegetated lake. North American Journal of Fisheries Manageent 18:286-294.

Norris AJ, DeVries DR, Wright RA (2010) Coastal Estuaries as Habitat for a Freshwater Fish Species: Exploring Population-Level Effects of Salinity on Largemouth Bass. Transactions of the American Fisheries Society 139:610-625

Noss RF (2011) Between the devil and the deep blue sea: Florida's unenviable position with respect to sea level rise. Climate Change 107:1-16

Orrock JL, Danielson BJ, Brinkerhoff RJ (2004) Rodent foraging is affected by indirect but not direct, cues of predation risk. Behavioral Ecology 15:433-437. 
Ostfeld R, Keesing F (2000) Pulsed resources and community dynamics of consumers in terrestrial ecosystems. Trends in Ecology and Evolution, 49:121-130.

Paetzold A, Schuber CJ, Tockner K (2005) Aquatic terrestrial linkages along a braided river: riparian arthropods feeding on aquatic insects. Ecosystems 8: 748-759

Parkos JJ, Ruetz CR, Trexler JC (2011) Disturbance regime and limits on benefits of refuge use for fishes in a fluctuating hydroscape. Oikos doi: 10.1111/j.16000706.2011.19178.x

Piovia-Scott J, Spiller DA, Schoener TW (2011) Effects of experimental seaweed deposition on lizard and ant predation in an island food web. Science 331: 461-462.

Polis GA, Anderson WB, Holt RD (1997) Toward an integration of landscape and food web ecology: The Dynamics of Spatially Subsidized Food Webs. Annual Reviews of Ecology, 28: 289-316.

Polis, GA, Hurd SD, Jackson CT, Pin'ero FS (1998) Multifactor population limitation: variable spatial and temporal control of spiders on Gulf of California island. Ecology 79:490-502.

Power ME, Dietrich I ( 2002) Food webs in river networks. Ecological Research 17:451471.

Rehage, JS, Trexler JC.( 2006) Assessing the net effect of anthropogenic disturbance on aquatic communities in wetlands: community structure relative to distance from canals. Hydrobiologia 569: 359-373

Rehage JS, Loftus W (2007) Seasonal fish community variation in headwater mangrove creeks in the southwestern everglades: an examination of their role as dry-down refuges. Bulletin of Marine Science 80:625-645

Rosenblatt AE, Heithaus MR (2011) Does variation in movement tactics and trophic interactions among American alligators creak habitat linkages? Journal of Animal Ecology. doi:10.1111/j.1365-2656.2011.01830.

Rozas LP, Minello T J (1997) Estimating densities of small fishes and decapod crustaceans in shallow estuarine habitats: A review of sampling design with focus on gear selection. Estuaries 20: 199-213

Scarnecchia DL (1992) A Reappraisal of Gars and Bowfins in Fishery Management. Fisheries 17:6-12 
Schindler DE, Scheurell MD, Moore JW, Gende SM, Francis TB, Palen WJ (2003)

Pacific salmon and the ecology of coastal systems. Frontiers in Ecology and Environment 1:31-37.

Schmitz OJ (2007) Predator diversity and trophic interactions. Ecology 88:2415-2426.

Sih A, Christensen B (2001) Optimal diet theory: when does it work and when does it fail? Animal Behavior 61:379-390.

Stevens P, Blewett D, Champeau T, Stafford C (2010) Posthurricane recovery of riverine fauna reflected in the diet of an apex predator. Estuaries and Coasts 33:59-66

Thierry A, Petchey OL, Beckerman AP, Warren PH, Williams RJ (2011) The consequences of size dependent foraging for food web topology. Oikos 120:493-502.

Trexler JC, Loftus WF, Perry S (2005) Disturbance frequency and community structure in a twenty-five year intervention study. Oecologia 145:140-152.

Valley RD, Bremigan MT (2002) Effects of macrophyte bed architecture on largemouth bass foraging: implications of exotic macrophyte invasions. Transactions of the American Fisheries Society,131, 234-244.

Winemiller KO (1989) Ontogenetic diet shifts and resource partitioning among piscivorous fishes in the Venezuelan llanos. Environmental Biology of Fishes 26: 177199.

Winemiller KO (1991) Comparative ecology of Serranochromis species (Teleostei: Cichlidae) in the Upper Zambezi River floodplain. Journal of Fish Biology 39: 617639

Winemiller, KO, Kelso-Winemiller LC (1994) Comparative ecology of the African pike, Hepsetus odoe, and tigerfish, Hydrocynus forskahlii, in the Zambezi River floodplain. Journal of Fish Biology 45: 211-225.

Winemiller KO, Jepsen DB (1998) Effects of seasonality and fish movement on tropical river food webs. Journal of Fish Biology 53:267-296

Wipfli MS, Baxter CV (2010) Linking ecosystems, food webs, and fish production: subsidies in salmonid watersheds. Fisheries 35:373-387

Wisenden BD, Thiel TA (2002) Field verification of predator attraction to minnow alarm substance. Journal of Chemical Ecology 28:433-438 
Woods J, Zucker M (2008) Coastal gradients of flow, salinity and nutrients. Annual summary report to the U.S. Army Corps of Engineers, Everglades National Park, and the U.S. Geological Society

Worm, B, Barbier EB, Beaumont N, Duffy JE, Folke C, Halpern BS, Jackson JBC, Lotze HC, Micheli F, Palumbi SR, Sala E, Selkoe KA, Stachowicz JJ, Watson R (2006) Impacts of biodiversity loss on ocean ecosystem services. Science 314: 787-790. doi:10.1126/science.1132294.

Yang LH (2005) Interactions between a detrital resource pulse and a detritivore community. Oceologia DOI 10.1007/s00442-005-0276-0

Yang LH, Bastow JL, Spence KO, Wright AN (2008) What can I learn from resource pulses. Ecology, 89: 624-634. 